\title{
Article
}

\section{Adsorption Kinetics of Cu(II) Species on Silica Gel in the Presence of Humic Acid}

\author{
*Sri Juari Santosa, Narsito and Ratna \\ Department of Chemistry, Faculty of Mathematics and Natural Sciences, Gadjah Mada University, \\ Sekip Utara Kotak Pos Bls. 21, Yogyakarta 55281, Indonesia
}

(Manuscript submitted March 23, 2007; accepted July 3, 2007)

\begin{abstract}
The adsorption kinetics and mechanism of two dissolved $\mathrm{Cu}$ (II) species, i.e. hydrated $\mathrm{Cu}$ (II) (Hy$\mathrm{Cu}(\mathrm{II}))$ and its humic acid complexed (HA-Cu(II)), on silica gel (SG) have been studied. The adsorption medium containing both $\mathrm{Hy}-\mathrm{Cu}(\mathrm{II})$ and $\mathrm{HA}-\mathrm{Cu}(\mathrm{II})$ was first prepared by introducing humic acid (HA) previously immobilized on SG into aqueous solution containing $\mathrm{Hy}-\mathrm{Cu}(\mathrm{II})$. The acidity of the solution was adjusted to $\mathrm{pH} 4.0$ in order the $\mathrm{Hy}-\mathrm{Cu}(\mathrm{II})$ to be proportionally distributed to HA$\mathrm{Cu}(\mathrm{II})$. The adsorption of the $\mathrm{Cu}(\mathrm{II})$ species on SG showed that $\mathrm{Hy}-\mathrm{Cu}(\mathrm{II})$ was adsorbed much faster than HA-Cu(II), with adsorption rate constant $\left(k_{a d}\right)$ of $0.48 \mathrm{~min}^{-1}$ for $\mathrm{Hy}-\mathrm{Cu}(\mathrm{II})$ and $0.05 \mathrm{~min}^{-1}$ for HA$\mathrm{Cu}(\mathrm{II})$. Since HA-Cu(II) complex should be anionic in nature, strong adsorption of the species on SG could not be expected. The adsorption energy $(E)$ of $24.82 \mathrm{~kJ} \mathrm{~mol}^{-1}$ for HA-Cu(II) complex which is significantly higher than that of $12.56 \mathrm{~kJ} \mathrm{~mol}^{-1}$ for $\mathrm{Hy}-\mathrm{Cu}(\mathrm{II})$ suggests that $\mathrm{HA}-\mathrm{Cu}(\mathrm{II})$ complex is chemically adsorbed through ligand exchange after the rapid electrostatic interaction through outersphere complexation of $\mathrm{Hy}-\mathrm{Cu}(\mathrm{II})$ on SG. This evidence indicates that the adsorption of the $\mathrm{Cu}(\mathrm{II})$ species proceeds sequentially, where the $\mathrm{Hy}-\mathrm{Cu}(\mathrm{II})$ is adsorbed first and it then acts as a bridge for the adsorption of $\mathrm{HA}-\mathrm{Cu}(\mathrm{II})$.
\end{abstract}

Key words: adsorption kinetics, $\mathrm{Cu}(\mathrm{II})$ species, silica gel, humic acid

\section{Introduction}

Metals in the aquatic environment may exist as hydrated metal ions, hydroxyl species, and metal complexes. The chemical speciation of metals controlling their toxicity and mobility depends largely on the nature of the metals and the surrounding substances.[1] Dissolved humic substances such as humic and fulvic acids are ubiquitous in the environment. They exist as natural weak polyelectrolytes that are very active in complexing cations.[2] The ability to complex cations is due to their unusual high content of oxygen-containing functional groups, which include $\mathrm{COOH}$, phenolic-, enolic-, alcoholic $\mathrm{OH}$, and $\mathrm{C}=\mathrm{O} .[2,3]$ Humic acid as a complexing agent has been known to have ability to solubilize metals.[4,5] Spark et al. [5] found that the formation of insoluble $\mathrm{M}(\mathrm{OH})_{2}$ species at higher $\mathrm{pH}$ value in the presence of dissolved humic acid is considerably less than that without the presence of humic acid.

For many years efforts have been spent to minimize the risk of metal leaching to groundwaters and to limit the uptake of the contaminants by crops.[6] This may be achieved by immobilizing metallic species through adsorption. Although the adsorption for contaminant removal from water has extensively been conducted, a novel adsorption process is always investigated due to lack of adequate knowledge of adsorption kinetics and especially adsorption mechanism.[7,8] Instead of kinetics and mechanism, capacity and energy are two parameters which are commonly determined in the adsorption.[9-11] Therefore, it is necessary to study adsorption kinetics and mechanism of metal species on particular adsorbent in which the system can represent the natural water system. However, adsorption study of metals in natural water is very complicated considering the metal speciation that may occur. In this study, an aqueous solution system was 
prepared to contain two species of $\mathrm{Cu}(\mathrm{II})$, i.e. hydrated $\mathrm{Cu}(\mathrm{II})\{\mathrm{hy}-\mathrm{Cu}(\mathrm{II})\}$ and humic acid complexed $\mathrm{Cu}(\mathrm{II})$ \{HA-Cu(II)\} . The adsorbent chosen was silica gel (SG) due to its reactive surface functional groups such as silanol, relatively low cost, and does not need any special complicated pretreatment.[12] The aim of this paper is therefore to study the adsorption kinetics and mechanism of $\mathrm{Hy}-\mathrm{Cu}(\mathrm{II})$ and $\mathrm{HA}-\mathrm{Cu}(\mathrm{II})$ on SG.

\section{Experimental}

\subsection{Material}

All reagents in analytical grade i.e. $\mathrm{Cu}\left(\mathrm{NO}_{3}\right)_{2} \cdot 5 \mathrm{H}_{2} \mathrm{O}, \mathrm{KOH}, \mathrm{KCl}, \mathrm{CaCl} 2, \mathrm{HCl}, \mathrm{HF}$, and $\mathrm{NaOH}$, were obtained from Merck Co Inc. (Germany) and used without further purification. Silica gel type G-60 used as support material for HA was also purchase from Merck Co Inc. (Germany), while three buffer solutions at $\mathrm{pH} 4.00,7.00$, and 10.00 for $\mathrm{pH}$ calibration were purchased from Fisher Scientific Co (Germany).

Humic acid was isolated from peat soil taken in Siantan Subdistrict, Pontianak, West Kalimantan, Indonesia, according to the procedure of International Humic Substances Society (IHSS).[13] The region in which the peat soil was collected was an area that has not been exposed by agricultural treatment and far from human intervention.

\subsection{Immobilization of HA on SG (HA-SG)}

Before immobilization, SG was first ultrasonically purified in $\mathrm{HCl}$ solution 1:10 for $15 \mathrm{~min}$. This ultrasonic assissted purification greatly reduces the purification time, since the purification of SG by stirring in $\mathrm{HCl}$ solution 1:10 withouth the assisstance of ultrasonic wave consumes $24 \mathrm{~h}$.[12] After purification, $66.7 \mathrm{~g} \mathrm{dm}^{-3} \mathrm{HA}$ solution in $0.01 M(\mathrm{M}=$ mol dm$\left.m^{-3}\right) \mathrm{NaOH}$ was then interacted with a suspension of $100 \mathrm{~g} \mathrm{dm}^{-3}$ the purified $\mathrm{SG}$ in $0.01 \mathrm{M} \mathrm{NaOH}$ according to the procedure described in our previous paper. [12] The resulted HA-SG contained $13.05 \%\left(\mathrm{w} \mathrm{w}^{-1}\right)$ HA.

\subsection{Speciation of $\mathrm{Cu}(\mathrm{II})$ as a Function of Medium Acidity}

The speciation of $\mathrm{Cu}(\mathrm{II})$ in aqueous solution containing HA-SG was carried out as follows. Into every $50 \mathrm{~cm}^{3}$ of $20 \mathrm{mg} \mathrm{dm}^{-3} \mathrm{Cu}$ (II) solution, $50 \mathrm{mg}$ HA-SG was added. The acidity of the mixtures was adjusted to $\mathrm{pH} \mathrm{2,} \mathrm{4,} \mathrm{6,} \mathrm{and} 7.5$ using either $\mathrm{HNO}_{3}$ or $\mathrm{NaOH}$ solution and aged overnight. The mixtures were then centrifuged at 10,000 rpm and followed by filtering to separate supernatants. The $\mathrm{Hy}-\mathrm{Cu}(\mathrm{II})$ in the supernatant was analyzed using $\mathrm{Cu}$ (II) ion selective electrode (ISE), while the total concentration of $\mathrm{Cu}$ (II) species was quantified using atomic absorption spectrometry (AAS). The concentration of $\mathrm{HA}-\mathrm{Cu}$ (II) was obtained by substracting the concentration of $\mathrm{Hy}-\mathrm{Cu}$ (II) from the total concentration of $\mathrm{Cu}$ (II) species.[14]

\subsection{Preparation of Sample Containing Hy-Cu(II) and HA-Cu(II)}

Sample containing both $\mathrm{Hy}-\mathrm{Cu}(\mathrm{II})$ and $\mathrm{HA}-\mathrm{Cu}(\mathrm{II})$ was prepared through the interaction between $50 \mathrm{mg}$ of HA-SG and 50 $\mathrm{cm}^{3}$ of $20 \mathrm{mg} \mathrm{dm}^{-3} \mathrm{Cu}$ (II) solution. The acidity of the mixture was adjusted to $\mathrm{pH} 4$ using $\mathrm{HNO}_{3}$ solution and aged for $24 \mathrm{~h}$. After centrifuging at 10,000 rpm and followed by filtering, the supernatant was then analyzed using $\mathrm{Cu}$ (II) ISE and AAS to quantify its $\mathrm{Hy}-\mathrm{Cu}(\mathrm{II})$ and total $\mathrm{Cu}(\mathrm{II})$ species contents, respectively. As performed above, the content of $\mathrm{HA}-\mathrm{Cu}(\mathrm{II})$ was obtained by substracting the concentration of $\mathrm{Hy}-\mathrm{Cu}(\mathrm{II})$ from the total concentration of $\mathrm{Cu}(\mathrm{II})$ species.[14]

\subsection{Adsorption Kinetics of $\mathrm{Hy}-\mathrm{Cu}(\mathrm{II})$ on SG}

Into $35 \mathrm{~cm}^{3}$ of the prepared sample above, the tip of the electrode of ISE was appropriately immersed and $35 \mathrm{mg}$ SG was then added. The signal of ISE was recorded continuously as a function of time for $2 \mathrm{~h}$. The concentration of $\mathrm{Cu}(\mathrm{II})$ adsorbed on SG as a function of time was calculated by subtracting the remaining concentration of $\mathrm{Hy}-\mathrm{Cu}(\mathrm{II})$ in solution from the initial concentration of $\mathrm{Hy}-\mathrm{Cu}(\mathrm{II})$ in the prepared sample. Based on the obtained data, the adsorption rate constant $\left(k_{a d}\right)$ and adsorption-desorption equilibrium constant $(K)$ of $\mathrm{Hy}-\mathrm{Cu}(\mathrm{II})$ on $\mathrm{SG}$ was then determined using the formulation of first order adsorption reaching equilibrium,[15] and the energy of adsorption $(E)$ was calculated according to the equation $E=R T \ln K .[10,11]$

\subsection{Adsorption Kinetics of HA-Cu(II) on SG}

The prepared samples were interacted with SG for 5, 10, 15, 20,30,60, and $120 \mathrm{~min}$, the mixtures were then centrifuged at 10,000 rpm and followed by filtering. The total concentration of $\mathrm{Cu}$ (II) species in the supernatant was analyzed using AAS. At corresponding interaction time, the difference between the concentration of $\mathrm{Cu}(\mathrm{II})$ analyzed using 
AAS and that using ISE is the remaining concentration of HA-Cu(II) in solution, while the difference between the remaining concentration of $\mathrm{HA}-\mathrm{Cu}$ (II) at corresponding interaction time and the initial concentration of $\mathrm{HA}-\mathrm{Cu}$ (II) gives the concentration of adsorbed HA-Cu(II). As conducted for $\mathrm{Hy}-\mathrm{Cu}(\mathrm{II})$, the adsorption parameters $\left(k_{a d}, K\right.$, and $\left.E\right)$ of $\mathrm{HA}$ $\mathrm{Cu}(\mathrm{II})$ on $\mathrm{SG}$ were then determined.

\section{Results and Discussion}

\subsection{Speciation of $\mathrm{Cu}(\mathrm{II})$ as a function of medium acidity}

The presence of HA-SG in $\mathrm{Cu}(\mathrm{II})$ solution caused $\mathrm{Cu}$ (II) to be distributed into three kinds of $\mathrm{Cu}$ (II) species, i.e. the remaining $\mathrm{Hy}-\mathrm{Cu}$ (II), the complex of $\mathrm{HA}-\mathrm{Cu}(\mathrm{II})$, and the adsorbed $\mathrm{Cu}(\mathrm{II})$ (Fig. 1). The distribution among these $\mathrm{Cu}$ (II) species was $\mathrm{pH}$ dependence. The $\mathrm{Hy}-\mathrm{Cu}$ (II)

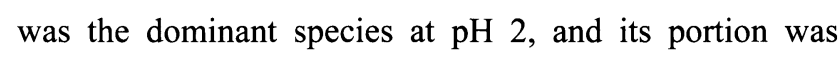
continuously reduced with decreasing the medium acidity. On the contrary, the portion of the adsorbed $\mathrm{Cu}$ (II) increased rapidly from it negligible portion at $\mathrm{pH} 2$ to become dominant species at $\mathrm{pH}$ higher than 5.5. In case of $\mathrm{HA}-\mathrm{Cu}(\mathrm{II})$, its portion slightly increased from $\mathrm{pH} 2$ to 4 and then gradually decreased at lower medium acidity.

Although the stability of HA toward dissolution improves substantially with the immobilization on SG, but close inspection shows that the dissolution of the

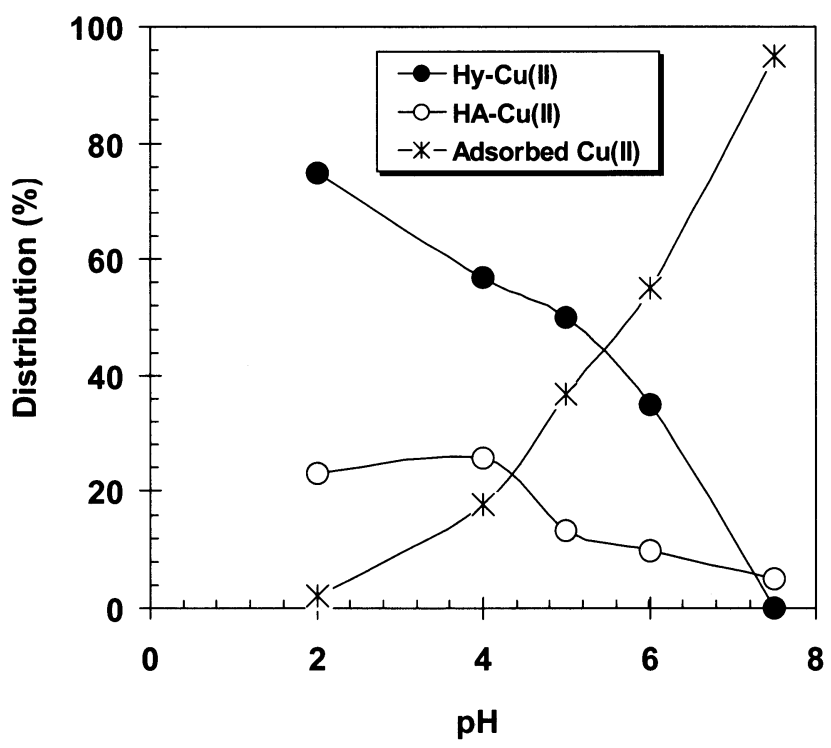

Fig. 1 Effect of $\mathrm{pH}$ on the distribution of $\mathrm{Cu}(\mathrm{II})$ species in aqueous solution of $\mathrm{Cu}$ (II) containing HA-SG immobilized HA still tends to increase with decreasing medium acidity from $\mathrm{pH} 2.0$ to 7.0. [12] Considering this increase of dissolution for the immobilized HA with decreasing medium acidity, it was surprising that above pH 4 , the portion of $\mathrm{HA}-\mathrm{Cu}(\mathrm{II})$ decreased with decreasing medium acidity (Fig. 1). This evidence may be interpreted that above $\mathrm{pH} 4$, the soluble HA-Cu(II) is re-immobilized on $\mathrm{Cu}(\mathrm{II})$-coated SG to form SG-Cu(II)-HA-Cu(II).

\subsection{Preparation of sample containing $\mathrm{Hy}-\mathrm{Cu}(\mathrm{II})$ and $\mathrm{HA}-\mathrm{Cu}(\mathrm{II})$}

For studying kinetics of simultaneous adsorption of $\mathrm{Hy}-\mathrm{Cu}(\mathrm{II})$ and $\mathrm{HA}-\mathrm{Cu}(\mathrm{II})$ on $\mathrm{SG}$, it is necessary to prepare first a sample containing both $\mathrm{Hy}-\mathrm{Cu}$ (II) and $\mathrm{HA}-\mathrm{Cu}$ (II) based on the results of $\mathrm{Cu}$ (II) speciation above. As shown in Fig. 1, $\mathrm{Hy}-\mathrm{Cu}(\mathrm{II})$ and $\mathrm{HA}-\mathrm{Cu}(\mathrm{II})$ existed on their closest concentration when the medium acidity was at $\mathrm{pH} 4.0$. For that reason, the preparation of sample solution containing both $\mathrm{Hy}-\mathrm{Cu}(\mathrm{II})$ and $\mathrm{HA}-\mathrm{Cu}(\mathrm{II})$ for the study of their simultaneous adsorption on SG was done at $\mathrm{pH} 4.0$.

\subsection{Adsorption kinetics of $\mathrm{Hy}-\mathrm{Cu}$ (II) and $\mathrm{HA}-\mathrm{Cu}$ (II) on SG}

Fig. 2 showed clearly that the adsorption of $\mathrm{Hy}-\mathrm{Cu}(\mathrm{II})$ on $\mathrm{SG}$ was much faster to reach equilibrium than the adsorption of $\mathrm{HA}-\mathrm{Cu}(\mathrm{II})$. Maximum adsorption of $\mathrm{Hy}-\mathrm{Cu}(\mathrm{II})$ was reached before the adsorption proceeded 1 min. Compared to $\mathrm{Hy}-\mathrm{Cu}(\mathrm{II})$, the adsorbed $\mathrm{HA}-\mathrm{Cu}(\mathrm{II})$ on $\mathrm{SG}$ was substantially slower. The adsorption still processed when the adsorption time reached $60 \mathrm{~min}$.

The less percentage of the adsorbed $\mathrm{Hy}-\mathrm{Cu}$ (II) than that of the adsorbed $\mathrm{HA}-\mathrm{Cu}$ (II) was due to the relatively higher initial concentration of $\mathrm{Hy}-\mathrm{Cu}$ (II) than $\mathrm{HA}-\mathrm{Cu}(\mathrm{II})$ in the prepared sample. The difference in their initial concentration could be seen at Fig. 1 where the $\mathrm{pH}$ was 4.0 . 
Parameters used to study the adsorption are the adsorption rate constant $\left(k_{a d}\right)$ and adsorption-desorption equilibrium constant $(K)$ which are specific for a reaction and has particular dimension depending on the order of reaction.[16] The $k_{a d}$ and $K$ of $\mathrm{Hy}-\mathrm{Cu}$ (II) and $\mathrm{HA}-\mathrm{Cu}(\mathrm{II})$ were separately determined using the formulation of the first order adsorption reaching equilibrium as shown below.[15] By plotting $\ln \left(C_{0} / C\right) / C$ versus $t / C$, a linear line will be obtained where the slope is $k_{a \mathrm{~d}}$ and the intercept is $K$. The application of the formulation to the adsorption data of Fig. 3 gave adsorption parameters as summarized in Table 1.

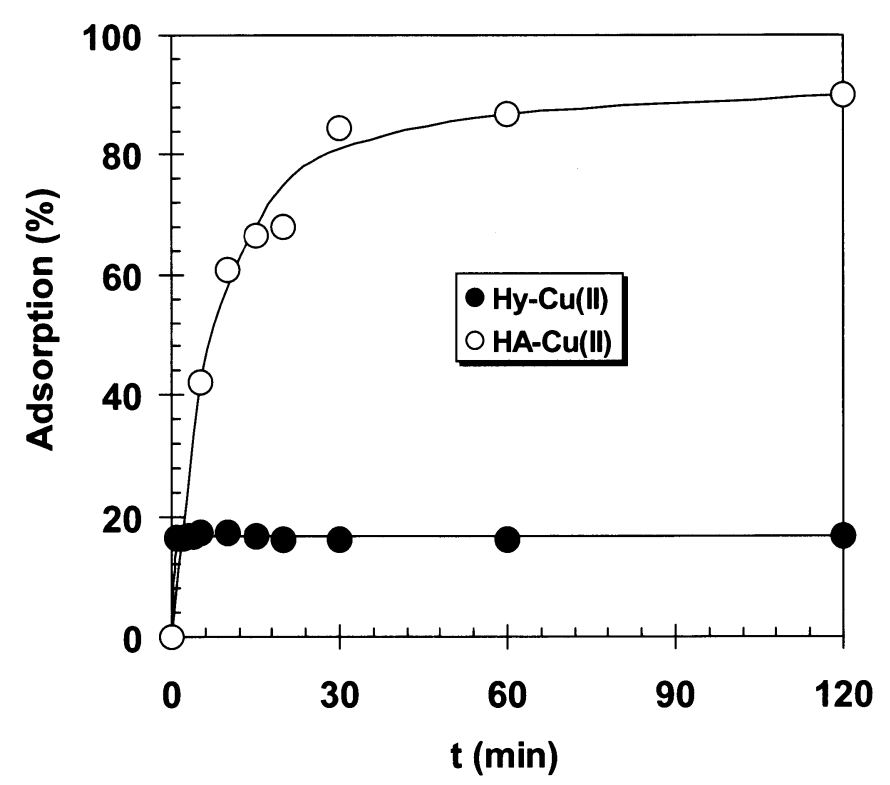

Fig. 2 Effect of contact time on the adsorption of $\mathrm{Cu}$ species on $\mathrm{SG}$ at $\mathrm{pH} 4.0$

$$
\frac{\ln \left(\frac{C_{0}}{C}\right)}{C}=k_{a d} \frac{t}{C}+K
$$

where $C_{0}$ is the initial concentration of adsorbed species $\left(\mathrm{mol} \mathrm{dm}{ }^{-3}\right), C$ is the remaining concentration of adsorbed species after sorption at $t$ sorption time $\left(\mathrm{mol} \mathrm{dm} \mathrm{dm}^{-3}\right), t$ is adsorption time ( $\left.\mathrm{min}\right), k_{a d}$ is adsorption rate constant $\left(\mathrm{min}^{-1}\right), K$ is adsorptiondesorption equilibrium constant $\left(\mathrm{mol}^{-1} \mathrm{dm}^{3}\right)$.

The adsorption rate constant of $\mathrm{Hy}-\mathrm{Cu}$ (II) was more than ten fold higher than that of HA$\mathrm{Cu}$ (II) (Table 1). This result leads to the assumption that the adsorption may proceed sequentially. Hy$\mathrm{Cu}$ (II) and HA- $\mathrm{Cu}$ (II) have different size and charge property which in turn will influence their rate of adsorption on SG. The size of $\mathrm{Hy}-\mathrm{Cu}(\mathrm{II})$ can be expected much smaller than that of $\mathrm{HA}-\mathrm{Cu}(\mathrm{II})$ but it is more positively charged.

In the prepared sample where the $\mathrm{pH}$ is 4 , the $\mathrm{SG}$ surface is coated with negative charges since its isoelectric point is about 3.[17,18] These negative charges tend to interact with positively charged species. Therefore, the excess of Hy$\mathrm{Cu}(\mathrm{II})$, which is smaller in size, would be adsorbed first on the surface of SG with high value of $k_{a d}$. In addition to the much bigger in size, the slow adsorption of HA-Cu(II) could be due to rearrangement within $\mathrm{HA}-\mathrm{Cu}$ (II) itself, which is initially considered spherical within boundaries hydrated with solvent,[19] while interact with the adsorbent surface. The overall adsorption reaction lead to the adsorbed $\mathrm{Hy}-\mathrm{Cu}(\mathrm{II})$ as cation bridge between negative charges of $\mathrm{SG}$ and $\mathrm{HA}-\mathrm{Cu}(\mathrm{II})$ as mentioned before.

The magnitude of $K$ which is

Table 1 Adsorption parameters and correlation coefficient $\left(R^{2}\right)$ of the plot of $\ln \left(C_{0} / C\right) / C$ vs $t / C$ for the adsorption of $\mathrm{Hy}-\mathrm{Cu}(\mathrm{II})$ and thermodynamic term does not relate to $k_{a d}$ which is kinetic term.[20] In this study, although the $k_{a d}$ of $\mathrm{Hy}-\mathrm{Cu}(\mathrm{II})$ was higher than that of $\mathrm{HA}-\mathrm{Cu}(\mathrm{II})$, but $\mathrm{Hy}-\mathrm{Cu}(\mathrm{II})$ has $K$ approximately 140 times lower than the $K$ of $\mathrm{HA}-\mathrm{Cu}$ (II) (Table 1). Therefore, the surface complexes formed from $\mathrm{HA}-\mathrm{Cu}(\mathrm{II})$ and the surface of SG are more stable. $\mathrm{HA}-\mathrm{Cu}(\mathrm{II})$ on $\mathrm{SG}$ at $\mathrm{pH} 4.0$

\begin{tabular}{ccccc}
\hline \multirow{2}{*}{$\begin{array}{c}\text { Adsorbed } \\
\text { species }\end{array}$} & $\begin{array}{c}k_{a d} \\
\left(\mathrm{~min}^{-1}\right)\end{array}$ & $\begin{array}{c}K \\
\left(\mathrm{~mol}^{-1} \mathrm{dm}^{3}\right)\end{array}$ & $\begin{array}{c}E^{*} \\
\left(\mathrm{~kJ} \mathrm{~mol}^{-1}\right)\end{array}$ & $R^{2}$ \\
\hline \hline Hy-Cu(II) & 0.49 & 159 & 12.6 & 0.980 \\
$\mathrm{HA}-\mathrm{Cu}(\mathrm{II})$ & 0.05 & 22,353 & 24.8 & 0.986 \\
\hline
\end{tabular}

The relation between $\mathrm{K}$ and energy of adsorption $(E)$ which is the energy changing during the adsorption $\left(\Delta G^{0}\right)$ is given by $E=-\Delta G^{0}=R T \ln K$.[10,11] According to this relationship, the energy evolved during the adsorption on SG was 12. $6 \mathrm{~kJ} \mathrm{~mol}^{-1}$ for $\mathrm{Hy}-\mathrm{Cu}(\mathrm{II})$ and $24.8 \mathrm{~kJ} \mathrm{~mol}^{-1}$ for $\mathrm{HA}-\mathrm{Cu}(\mathrm{II})$. The adsorption of $\mathrm{Hy}-\mathrm{Cu}(\mathrm{II})$ forming less stable complexes 
on SG. In attracting $\mathrm{Hy}-\mathrm{Cu}(\mathrm{II})$, the active site of SG, which is mainly composed negatively charged oxygen from the ionized silanol group, will be hindered by water molecules surrounding $\mathrm{Cu}$ (II). Therefore, the adsorption of $\mathrm{Hy}-\mathrm{Cu}$ (II) on SG is dominantly directed by electrostatic interactions through outer-sphere complexation of $\mathrm{Cu}(\mathrm{II})$ on negatively charged ionized silanol group. In this electrostatic interaction to form an outer-sphere complexation, both ionized hydroxyl group and $\mathrm{Cu}(\mathrm{II})$ maintain their hydration sheath. Electrostatic interaction through outer-sphere complexation is typically rapid and the interaction is relatively weak in nature.[21]

In the second step of adsorption, the degree of electrostatic interaction between $\mathrm{Cu}$ (II)-coated SG and HA-Cu(II) is not as large as that between $\mathrm{Cu}$ (II) and the negatively charged ionized hydroxyl group on SG surface. It can be understood since part of the negative charges of the dissolved HA has been neutralized by $\mathrm{Cu}$ (II) to form complex substance. Therefore, the adsorption is assumed to be favored by ligand exchange between bound water molecule on the adsorbed $\mathrm{Cu}(\mathrm{II})$ on $\mathrm{SG}$ and oxygen on the remaining ionized carboxyl groups of $\mathrm{HA}-\mathrm{Cu}(\mathrm{II})$. In this mode of interaction, the hydration sheath has no longer been maintained, and consequently a strong chemical bond is formed.

The above suggestions were in agreement with the results obtained from the kinetic study of selenite adsorption on goethite surface.[22] Two steps of adsorption were involved, i.e. rapid formation of outer-sphere surface complex through electrostatic interaction was in the first step and followed by the slower formation of inner-sphere complex for the second step.

\section{References}

1) S.E. Manahan, "Environmental Chemistry" (Seventh Edition), Lewis Publisher, Boca Raton (2000), Chap. 3, pp. 5598.

2) F.J. Stevenson, "Humus Chemistry" (Second Edition), John Wiley \& Sons, Inc., New York (1994), Chap. 9, pp. 212235.

3) G.R. Aiken, D.M. McKnight, R.I. Wershaw, and P. MacCarthy, "Humic Substances in Soil, Sediment and Water: Geochemistry, Isolation, and Characterization”, John Wiley \& Sons, New York (1985), Chap. 4, pp. 183-231.

4) J. Van den Bergh, B. Jakubowski, and P. Burba, "Characterisation of Aquatic Humic Substance-Metal Species and Their Stability by Combining EDTA Exchange, Ultrafiltration and Atomic Spectrometry in: Understanding \& Managing Organic Matter in Soils, Sediments \& Waters (Eds. R. S. Swift and K. M. Spark), Hyde Park Press, Adelaide (2001), Section 5, pp. 509-515.

5) K.M. Spark, J.D. Wells, and B.B. Johnson, Aust. J. Soil. Resc., 35, 89 - 101 (1997).

6) N. Bunce, "Environmental Chemistry" (Second Edition), Wuerz Publishing Ltd., Winnipeg (1994), Chap. 5, pp. 131157.

7) R.A. Dianati-Tilaki and S. Mahmood, Pakistan J. Biol. Sci., 7(5), 865 - 869 (2004).

8) S. Azizian, J. Colloid. Interface Sci., 276, 47 - 52 (2004).

9) S. Goswami and C. Ghosh, Water $S A, 31(4), 597$ - 602 (2005).

10) A.K. Jain., V.K. Gupta, S. Jain, and Suhas, Environ. Sci. Technol., 38, 1195 - 1199 (2004).

11) M. Dader, M. Colilla, and E.R-Hitzky, Chem. Mater., 15, 3774 - 3780 (2003).

12) S.J. Santosa, S. Sudiono, and Sujandi, e-J. Surf. Sci. Nanotech., 4, 602 - 608 (2006).

13) G. Calderoni and M. Schnitzer, Geochim. Cosmochim. Acta, 48, 2045 - 2049 (1984).

14) J. Wu, L.J. West, and D.I. Stewart, J Hazard. Mat., 94, 223 - 238 (2002)

15) S.J. Santosa, D. Siswanta, A. Kurniawan, and W.H. Rahmanto, Surf. Sci., (2007) in press.

16) J.H. Espenson, "Chemical Kinetics and Reaction Mechanism" (Second Edition), McGraw-Hill, Belmont (1986), Chap. 6 , pp. $340-362$. 
17) S. Kondo, "Colloid Silicas in: Adsorption on New and Modified Inorganic Sorbent" (Eds. A. Dabrowski and V.A. Tertykh), Studies in Surface Science and Catalysis, Elsevier, New York (1996), Vol. 99, pp. 93 - 113.

18) K.M. Spark, J.D. Wells, and B.B. Johnson, Aust. J. Soil. Resc., 35, 103 - 112 (1997).

19) M.H.B. Hayes, "Extraction of Humic Substances from Soil in: Humic Substances in Soil, Sediment and Water: Geochemistry, Isolation, and Characterization" (Eds. M.H.B. Hayes and W.S. Wilson), The Royal Society of Chemistry, UK, $3-27$.

20) B. Douglas, D. Mc Daniel, and J. Alexander, “Concept and Model of Inorganic Chemistry” (Third Edition), John Wiley \& Sons, New York (1994), Chap. 11, pp. 482-557.

21) D.A. Dzombak and F.M.M. Morel, "Surface Complexation Modeling”, John Wiley \& Sons, New York (1990), Chap. 5, pp. 306-325.

22) P.C. Zhang and D.L. Spark, Environ. Sci. Technol., 24, 1848 - 1856 (1990). 